Pesq. Vet. Bras. 38(1):143-146, janeiro 2018 DOI: $10.1590 / \mathrm{S} 0100-736 \mathrm{X} 2018000100023$

\title{
Serological survey of anti-Leptospira spp. antibodies in Barbary sheep (Ammotragus lervia) at the Curitiba Zoo, southern Brazil ${ }^{1}$
}

\author{
Vivien M. Morikawa ${ }^{2,3}$, Cristina K. Zimpel², Igor A.D. Paploski ${ }^{4}$, Mariana Kikuti ${ }^{4}$, Vanessa \\ Castro $^{5}$, Marcia O. Lopes ${ }^{6}$, Alexander W. Biondo ${ }^{2,3 *}$ and Ivan R. de Barros Filho ${ }^{2}$
}

\begin{abstract}
Morikawa V.M., Zimpel C.K., Paploski I.A.D., Kikuti M., Castro V., Lopes M.O., Biondo A.W. \& Barros Filho I.R. 2018. Serological survey of anti-Leptospira spp. antibodies in Barbary sheep (Ammotragus lervia) at the Curitiba Zoo, southern Brazil. Pesquisa Veterinária Brasileira 38(1):143-146. Departamento de Medicina Veterinária, Setor de Ciências Agrárias, Universidade Federal do Paraná, Rua dos Funcionários 1540, Cabral, Curitiba, PR 80035-050, Brazil. E-mail: abiondo@ufpr.br

Leptospirosis is a worldwide zoonosis, affecting humans, domestic and wild animals. The present study aimed to evaluate prevalence of anti-Leptospira spp. antibodies in Barbary sheep at the Curitiba zoo. Microscopic agglutination test (MAT) was performed using 17 serogroups. Antibodies against Leptospira spp. were observed in $23.5 \%$ samples and Icterohaemorrhagiae was the only prevalent serogroup. The presence of anti-Leptospira antibodies in Barbary sheep indicates exposure to leptospires; thus monitoring and preventive measures are necessary in zoo's captive animals, since they can act as sentinels of environmental exposure in an area with high movement of people.
\end{abstract}

INDEX TERMS: Anti-Leptospira antibodies, Barbary sheep, Ammotragus lervia, leptospirosis, zoo, bacterioses.

RESUMO.- [Estudo sorológico de anticorpos anti-Leptospira spp. em aoudads (Ammotragus lervia) no zoológico de Curitiba, sul do Brasil.] A leptospirose é uma zoonose mundial que afeta seres humanos, animais domésticos e selvagens. 0 presente estudo objetivou avaliar a prevalência de anticorpos anti-Leptospira spp. em aoudads do zoológico de Curitiba. Foi realizado o teste de Soroaglutinação microscópica (SAM) utilizando 17 sorogrupos. Anticorpos contra Leptospira spp. foram observados em $23.5 \%$ das amostras de aoudads e Icterohaemorrhagiae foi o único sorogrupo prevalente. A presença de anticorpos em

\footnotetext{
${ }^{1}$ Received on August 16, 2015.

Accepted for publication on December 9, 2016.

${ }^{2}$ Departamento de Medicina Veterinária, Setor de Ciências Agrárias, Universidade Federal do Paraná. Rua dos Funcionários 1540, Cabral, Curitiba, PR 80035-050, Brazil. *Corresponding author: abiondo@ufpr.br

${ }^{3}$ Departamento de Pesquisa e Conservação da Fauna, Secretaria Municipal do Meio Ambiente, Curitiba, PR 80020, Brazil.

${ }^{4}$ Instituto de Saúde Coletiva, Universidade Federal da Bahia, Salvador, BA 40110, Brazil.

${ }^{5}$ Instituto Biológico - Centro de Pesquisa e Desenvolvimento de Sanidade Animal, São Paulo, SP 04014, Brazil.

${ }^{6}$ Departamento de Saúde Comunitária, Setor de Ciências da Saúde, Universidade Federal do Paraná, Rua Padre Camargo 280, Alto da Glória, Curitiba, PR 80060-240, Brazil.
}

aoudads indica exposição a leptospiras portanto monitoramento e medidas preventivas são necessários em animais confinados em zoológicos, uma vez eles podem atuar como sentinelas de exposição ambiental em uma área com alta circulação de pessoas.

TERMOS DE INDEXAÇ̃̃O: Anticorpos anti-Leptospira spp., aoudads, Ammotragus lervia, leptospirose, zoológico, bacterioses.

\section{INTRODUCTION}

Leptospirosis is an important worldwide zoonosis transmitted mainly by rats, Rattus norvegicus, in urban areas (Adler \& De la Pena Moctezuma 2010). It is an acute infectious disease, which affects humans, domestic and wild animals, causing economic losses in livestock and of great importance in public health (Faine et al. 1999).

In developing countries, a higher incidence of the disease is related to high temperatures and rainfall, during specific periods of the year (Tassinari et al. 2008). Around 10,000 cases of human leptospirosis are reported in Brazil every year (McBride et al. 2005) and case-fatality rates range from 10.0 to $15.0 \%$ (Ko et al. 1999) in patients with classical clinical manifestation (also known as Weil's syndrome), but can be as high as $74.0 \%$ in patients that develops severe pulmonary hemorrhagic syndrome (Gouveia et 
al. 2008). Curitiba has reported an average of 135 human leptospirosis cases per year in the past five years (SINAN 2014) and is among the cities with the highest human mortality rates from leptospirosis in Parana state (SMS 2011).

Wildlife may act as reservoirs to specific serogroups of Leptospira and the exposure to captive wild animals at zoos can be an important source of zoonotic infection (Chomel et al. 2007). Free-ranging wild animals are exposed to a huge variety of Leptospira serogroups and usually exhibit anti-Leptospira antibody titers to serogroups native of its areas. However, in captivity, the common environment of a wide range of potential reservoirs and hosts may result in exposure to a variety of serogroups (Luna-Alvarez et al. 1996, Ullmann et al. 2012a).

Some species, such as the Barbary sheep (Ammotragus lervia) have the potential to act as hosts, and probably reservoirs for important infectious diseases (Candela et al. 2009). Previous surveys showed evidence of infection or exposure to pathogens as Mycobacterium bovis, Mycobacterium paratuberculosis, Salmonella spp., Toxoplasma gondii and Neospora caninum in Barbary sheep (Candela et al. 2009, Morikawa et al. 2014). Serological monitoring of pathogen exposure in zoo captive animals may help understanding the susceptibility of these species to infectious agents as well as a guide to preventive measures considering the high circulation of human visitors. Thus, the present study aimed to evaluate prevalence of anti-Leptospira spp. antibodies in Barbary sheep at the Curitiba zoo.

\section{MATERIALS AND METHODS}

Curitiba zoo is among the largest Brazilian zoos with approximately 2,300 animals of 300 species, distributed across 530 square meters area (Javorouski \& Biscaia 2012). All 17 captive-born Barbary sheep, otherwise healthy animals, from Curitiba zoo were included in the present study. Each animal was uniquely identified and individual information such as age, sex and housing location were collected. Blood samples were obtained by jugular venipuncture (Fig.1, 2). Serum was obtained by centrifugation at $3,000 \mathrm{rpm}$ for 5 minutes and stored at $-20^{\circ} \mathrm{C}$ until testing.

Microscopic agglutination test (MAT) using a cut-off titer of 100 was performed (Faine et al. 1999). Seventeen serogroups

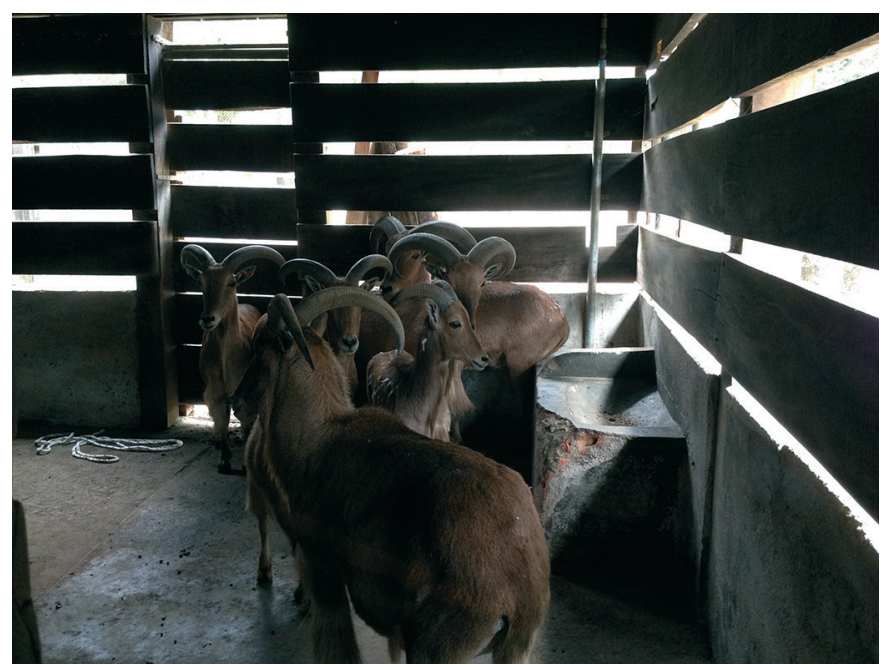

Fig.1. Group of non-visitation Barbary sheep.

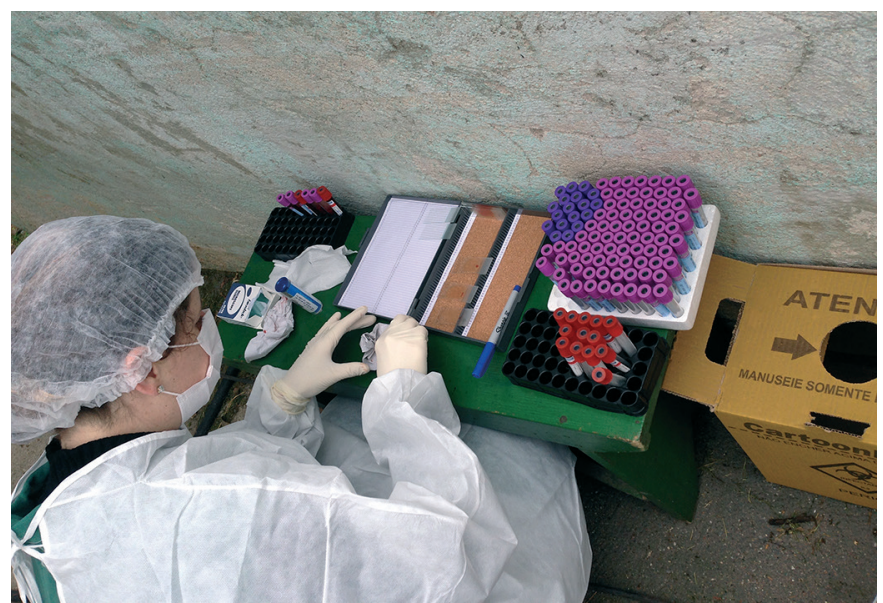

Fig.2. Blood sampling of Barbary sheep.

were tested: Australis (serovars Australis and Bratislava), Autumnalis (serovars Autumnalis and Butembo), Ballum (serovar Castellonis), Bataviae (serovar Bataviae), Canicola (serovar Canicola), Celledoni (serovar Whitcombi), Cynopteri (serovar Cynopteri), Djasiman (serovar Sentot), Grippotyphosa (serovar Grippotyphosa), Hebdomadis (serovar Hebdomadis), Icterohaemorrhagiae (serovars Copenhageni and Icterohaemorrhagiae), Javanica (serovar Javanica), Panama (serovar Panama), Pomona (serovar Pomona), Pyrogenes (serovar Pyrogenes), Sejroe (serovars Hardjo and Wolffi) and Shermani (serovars Shermani and Tarassovi).

Both laboratory and epidemiological data were entered into an Excel spreadsheet. Contingency tables for associations were created in Epi Info 7 (CDC, 2013) and analyzed in OpenEpi (Dean et al. 2013). Prevalence ratios and $95 \%$ confidence intervals were calculated, and Fisher's exact test was used to compare proportions between variables at a 5\% significance level.

\section{RESULTS}

Antibodies against Leptospira spp. were observed in $23.53 \%$ (4/17) Barbary sheep sampled. Prevalence of serologic evidence of exposure to pathogen was stratified by age, sex and housing condition (public display or isolation area) (Table 1). The mean age of the sampled animals was 5 years, with a standard deviation of 2.7 years. The prevalence of anti-Leptospira spp. antibodies in animals aged $\geq 5$ years was 0.5 (95\% CI: $0.1-3.7$ ) times the observed in animals aged $<5$ years $(p$-value $=0.60)$. None of the fema-

Table 1. Prevalence of anti-Leptospira spp. antibodies stratified by age, sex and housing location

\begin{tabular}{lcccc}
\hline Characteristic & \multicolumn{4}{c}{ Anti-Leptospira sp. antibodies } \\
\cline { 2 - 5 } & $\mathrm{n} / \mathrm{N}$ & $\%$ & PR (CI 95\%)** & $\mathrm{p}$-value \\
\hline Age & & & & \\
$\quad<5$ years & $3 / 10$ & 30.0 & - & - \\
$\quad$ 5 years & $1 / 7$ & 14.3 & $0.5(0.1-3.7)$ & 0.60 \\
Sex & & & & - \\
$\quad$ Female & $0 / 7$ & 0.0 & - & 0.10 \\
$\quad$ Male & $4 / 10$ & 40.0 & $\mathrm{NA}^{*}$ & \\
Housing & & & & - \\
$\quad$ Isolation & $1 / 12$ & 8.3 & - & 0.05 \\
$\quad$ Public display & $3 / 5$ & 60.0 & $7.2(0.97-53.6)$ &
\end{tabular}

** Prevalence ratio (95\% confidence interval).

* Not applicable.

$\mathrm{n}=$ Total number of seropositive animals.

$\mathrm{N}=$ Total number of sampled animals. 
le animals were seropositive $(0 / 7)$ whereas $40 \%$ of males $(4 / 10)$ presented anti-Leptospira antibodies. Seroprevalence among the animals housed on public display was 7.2 times higher than those in the isolation area (Prevalence ratio: 7.2; 95\% CI: 0.97-53.6; p-value $=0.05$ ). All four seropositive animals presented antibodies titer ranging from 100 to 400 for serogroup Icterohaemorrhagiae.

\section{DISCUSSION}

The present study has identified the seroprevalence of $23.53 \%$ (4/17) of anti-Leptospira spp. antibodies in Barbary sheep at the Curitiba zoo however none of them have shown any clinical signs of infection, such as reproductive diseases. Similar prevalence has been described in previous studies with captive wild animals in different Brazilian cities, from zoos and research centers. Several animals species were studied, such as lion tamarins in Rio de Janeiro (Lilenbaum et al. 2005), New World monkeys in Salvador (Pinna et al. 2012), llama, crab-eating fox, maned wolf, coatimundi, zebra, spider monkey (Lilenbaum et al. 2002), yagouaroundi, margay, mountain lion and jaguar (Lilenbaum et al. 2004) in Rio de Janeiro Zoo, and captive neotropical felids in Foz do Iguaçu (Guerra Neto et al., 2004). Prevalence in these studies ranged from $5.68 \%$ to $56.8 \%$ and Icterohaemorrhagiae was one of the predominant serovars (Corrêa et al. 2004, Esteves et al. 2005, Guerra Neto et al. 2004, Lilenbaum et al. 2005, Pimentel et al. 2009, Pinna et al. 2012, Ullmann et al. 2012b). Captivity in zoos may allow contact of wild animals to free-ranging wild and sinantropic animals such as rodents, raccoons, opossums and stray dogs due to close proximity of both urban and sylvatic environments. These animals can be considered reservoirs or hosts of leptospires (Faine et al. 1999). Particularities of environmental settings where urban zoos are located can explain the predominance of Icterohaemorrhagiae serogroup in this study. This serogroup is commonly reported in urban areas of Latin America affecting humans and animal, carried by Rattus norvegicus (Ko et al. 1999).

Curitiba zoo is located in Iguaçu Municipal Park, an area with humid subtropical climate with an average annual temperature of $16^{\circ} \mathrm{C}$ (IBGE 2010), which gives favorable conditions to the survival of leptospires in the environment, for several months (Faine \& Stallman 1982, Langston \& Heuter 2003). Previous studies were conducted in an adjacent area to the Curitiba zoo, also located in Iguaçu Municipal Park, called Vila Pantanal, a riverside slum community where human leptospirosis is considered endemic, where Leptospira spp. seroprevalence was established for owned dogs and cart horses. The first study showed Leptospira spp. antibody prevalences of $9.2 \%$ and $16.0 \%$ in sampled dogs, Canicola and Icterohaemorrhagiae as the predominant serogroups (Morikawa 2010). An even higher prevalence of antibodies against Leptospira spp. was observed in cart horses (75.8\%), also with Icterohaemorrhagiae as the most frequent serogroup (80.8\%) (Finger et al. 2014). In this area, poor sanitary conditions and infrastructure, proximity to garbage dump sites and open sewers and flooding were associated to seroprevalence of leptospirosis (Bier et al. 2012, Finger et al. 2014). Since Vila Pantanal and
Curitiba zoo are both located in Iguaçu Municipal Park and Iguaçu River go through them, it may be considered that animals from both places are submitted to the same environmental conditions and risk factors. Thus, it is possible to expect the occurrence of same serovar Icterohaemorrhagiae.

Presence of rodents at the Curitiba zoo is a critical problem and since they are the reservoirs to leptospirosis, measures of control need to be implemented. Chemical control is only applied in specific situations. Efforts are focused on preventing and diminishing conditions for the establishment of these synanthropic animals, which can be challenging due to the management of resident captive animals. Zoo staff is periodically trained to avoid leaving waste on the ground, keeping disposal containers closed and feeders properly cleaned, with an emphasis on the usage of personal protective equipment, especially in area prone to flooding inside the zoo.

Due to a small number of animals tested, this study did not have enough statistical power to detect factors associated with higher prevalence of anti-Leptospira spp. antibodies in Barbary sheep. Still, it is noteworthy that out of all animals from this species kept at the zoo, a higher prevalence was found in younger, male and housed in public display animals. A couple of hypothesis may be raised to address these findings, such as behavioral attitudes of younger and male animals predisposing exposure to leptospires on the environment and higher environmental exposure in public display housings. Exhibiting captive animals on public display in open enclosures may be at higher risk of infection, as previously observed in a seroepidemiology survey of infectious diseases in zoos (De Camps et al. 2008). Further studies are necessary to better understand these findings. A borderline significant $P$ value for the association of public housing display and higher seroprevalence highlights a worrisome situation, where visitors may also be exposed to higher environmental exposure to this pathogen.

Although leptospirosis does not appear to be a significant clinical issue for Barbary sheep at the Curitiba zoo and seropositive animals presented low titers, a $23.53 \%$ overall prevalence may indicate environmental exposure to leptospires. This is particularly important since animals in public display housing had higher seroprevalence, raising concerns regarding environmental exposures to visitors. This issue is being address with continuous training to the zoo staff. Since information about the use of vaccines in Barbary sheep is still limited, serological monitoring of these captive wild animals in zoos is indispensable and may provide a better understanding of health hazards that ultimately will aid in species conservation by comprehending reservoir potential, public health impact and on guiding specific preventive measures.

\section{REFERENCES}

Adler B. \& De la Pena Moctezuma A. 2010. Leptospira and leptospirosis. Vet. Microbiol. 140:287-296.

Bier D., Martins-Bedê F.T., Morikawa V.M., Ullmann L.S., Kikuti M., Langoni H., Canever R.J., Biondo A.W. \& Molento M.B. 2012. Spatial distribution of seropositive dogs to Leptospira spp. and evaluation of leptospirosis risk factors using a decision tree. Acta Scient. Vet. 40:1054. 
Candela M.G., Serrano E., Martinez-Carrasco C., Martin-Atance P., Cubero M.J., Alonso F. \& Leon L. 2009. Coinfection is an important factor in epidemiological studies: the first serosurvey of the aoudad (Ammotragus lervia). Eur. J. Clin. Microbiol. Infect. Dis. 28:481-489.

CDC 2013. Centers for Disease Control and Prevention, Atlanta, GA.

Chomel B.B., Belotto A. \& Meslin F.X. 2007. Wildlife, exotic pets, and emerging zoonoses. Emerg. Infect. Dis. 13:6-11.

Corrêa S.H.R., Vasconcellos S.A., Morais Z., Teixeira A.A., Dias R.A., Guimarães M.A.B.V., Ferreira F. \& Ferreira Neto J.S. 2004 Epidemiologia da Leptospirose em animais silvestres na Fundação Parque Zoológico de São Paulo. Braz. J. Vet. Res. Anim. Sci. 41:189-193.

De Camps S., Dubey J.P. \& Saville W.J. 2008. Seroepidemiology of Toxoplasma gondii in zoo animals in selected zoos in the midwestern United States. J. Parasitol. 94:648-653.

Dean A.G., Sullivan K.M. \& Soe M.M. 2013. OpenEpi: Open Source Epidemiologic Statistics for Public Health, Version.

Esteves F.M., Guerra-Neto G., Girio R.J.S., Silva-Vergara M.L., Carvalho A.C. F.B. 2005. Detecção de anticorpos para Leptospira spp. em animais e funcionários do Zoológico Municipal de Uberaba, MG. Arqs Inst. Biológico, São Paulo, 72:283-288.

Faine S., Adler B., Bolin C. \& Perolat P. 1999. Leptospira and Leptospirosis. MedSci, Melbourne. 272p.

Faine S. \& Stallman N.D. 1982. Amended descriptions of the genus Leptospira Noguchi, 1917 and the species L. interrogans (Stimson, 1907) Wenyon, 1926 and L. biflexa (Wolbach et Binger, 1914) Noguchi, 1918. Int. J. System. Bacteriol. 32:461-463.

Finger M.A., Barros Filho I.R., Leutenegger C., Estrada M., Ullmann L.S., Langoni H., Kikuti M., Dornbush P.T., Deconto I. \& Biondo A.W. 2014. Serological and molecular survey of Leptospira spp. among cart horses from an endemic area of human leptospirosis in Curitiba, southern Brazil. Revta Inst. Med. Trop., São Paulo, 56:473-476.

Gouveia E.L., Metcalfe J., Fe Carvalho A.L., Aires T.S., Villasboas-Bisneto J.C., Queirroz A., Santos A.C., Salgado K., Reis M.G. \& Ko A.I. 2008. Leptospirosis-associated severe pulmonary hemorrhagic syndrome, Salvador, Brazil. Emerg. Infect. Dis. 14:505-508.

Guerra Neto G., Girio R.J.S., De Andrade T.M., Koproski L.P., De Moraes W. \& Dos Santos L.C. 2004. Ocorrência de anticorpos contra Leptospira spp. em felídeos neotropicais pertencentes ao criadouro de animais silvestres da Itaipu Binacional e ao Zoológico Municipal Bosque Guarani, Foz do Iguaçu, Estado do Paraná. Ars Vet. 20:75-80.

IBGE 2010. Population Estimates for Curitiba. Instituto Brasileiro de Geografia e Estatística, Brazil.

Javorouski M.L. \& Biscaia S.A. 2012. Zoológico Municipal de Curitiba 30 anos, Curitiba.

Ko A.I., Galvao Reis M., Ribeiro Dourado C.M., Johnson Jr W.D. \& Riley L.W. 1999. Urban epidemic of severe leptospirosis in Brazil. Salvador Leptospirosis Study Group. Lancet 354:820-825.
Langston C.E. \& Heuter K.J. 2003. Leptospirosis: a re-emerging zoonotic disease. Vet. Clin. N. Am., Small Anim. Pract. 33:791-807.

Lilenbaum W., Monteiro R.V., Ristow P., Fraguas S., Cardoso V.S. \& Fedullo L.P. 2002. Leptospirosis antibodies in mammals from Rio de Janeiro Zoo, Brazil. Res. Vet. Sci. 73:319-321.

Lilenbaum W., Monteiro R.V., Albuquerque C.E., Ristow P., Fraguas S., Cardoso V.S. \& Fedullo L.P. 2004. Leptospiral antibodies in wild felines from Rio de Janeiro Zoo, Brazil. Vet. J. 168:191-193.

Lilenbaum W., Varges R., Moraes I.A., Ferreira A.M. \& Pissinatti A. 2005. Leptospiral antibodies in captive lion tamarins (Leontopithecus sp.) in Brazil. Vet. J. 169:462-464.

Luna-Alvarez M.A., Moles-Cervantes L.P., Torres-Barranca J.I. \& Gual-Sill F. 1996. Investigación serológica de leptospirosis en fauna silvestre mantenida en cautiverio en el zoológico de Chapultepec de la ciudad de México. Vet. México 27:229-234.

McBride A.J., Athanazio D.A., Reis M.G. \& Ko A.I. 2005. Leptospirosis. Curr. Opin. Infect. Dis. 18:376-386.

Morikawa V.M. 2010. Estudo sorológico da infecção por Leptospira spp. em uma área de ocupação irregular e alto risco para a doença em cães em Curitiba, PR. Disssertação de Mestrado, Universidade Federal do Paraná, Curitiba.

Morikawa V.M., Zimpel C.K., Paploski I.A., Lara M.C., Villalobos E.M., Romaldini A.H., Okuda L.H., Biondo A.W. \& Barros Filho I.R. 2014. Occurrences of anti-Toxoplasma gondii and anti-Neospora caninum antibodies in Barbary sheep at Curitiba zoo, southern Brazil. Revta Bras. Parasitol. Vet. 23:255-259.

Pimentel J.S., Gennari S.M., Dubey J.P., Marvulo M.F.V., Vasconcellos S.A., Morais Z.M., Silva J.C.R. \& Evêncio Neto J. 2009. Inquérito sorológico para toxoplasmose e leptospirose em mamíferos selvagens neotropicais do Zoológico de Aracajú, Sergipe. Pesq. Vet. Bras. 29:1009-1014.

Pinna M.H., Martins G., Pinheiro A.C., Almeida D.S., Oria A.P. \& Lilenbaum W. 2012. Detection of anti-Leptospira antibodies in captive nonhuman primates from Salvador, Brazil. Am. J. Primatol. 74:8-11.

SINAN 2014. Leptospirose: casos confirmados notificados no Sistema de Informação de Agravos de Notificação. Ministério da Saúde, Brazil.

SMS 2011. Leptospirose: situação atual em Curitiba. Bolm Epidemiol. 1. Secretaria Municipal de Saúde de Curitiba, p.2-3.

Tassinari W.S., Pellegrini D.C., Sa C.B., Reis R.B., Ko A.I. \& Carvalho M.S. 2008. Detection and modelling of case clusters for urban leptospirosis. Trop. Med. Intern. Health 13:503-512.

Ullmann L.S., Hoffmann J.L., De Moraes W., Cubas Z.S., Dos Santos L.C., Da Silva R.C., Moreira N., Guimaraes A.M., Camossi L.G., Langoni H. \& Biondo A.W. 2012a. Serologic survey for Leptospira spp. in captive neotropical felids in Foz do Iguacu, Parana, Brazil. J. Zoo. Wildl. Med. 43:223-228.

Ullmann L.S., Neto R.N.D., Teixeira H.F., Nunes A.V., Silva R.C., Pereira-Richini V.B. \& Langoni H. 2012b. Epidemiology of leptospirosis at Sorocaba Zoo, São Paulo state, Southeastern Brazil. Pesq. Vet. Bras. 32:1174-1178. 